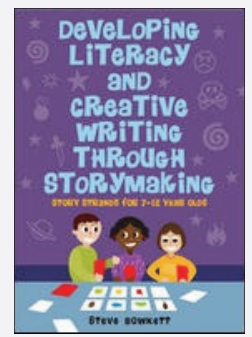

\title{
Creando historias
}

por Celso Manuel Fernández Valcárcel, Adela Fuentes Canosa y Patricia Rodríguez Groba

Bowkett, Steve (2010). Developing Literacy and Creative Writing through Storymaking: story strands for 7-12 year olds.

Maidenhead: Ed. Open University Press \& McGraw - Hill Education.

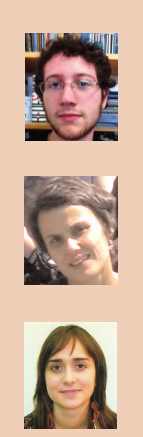

Celso Manuel Fernández Valcárce

Estudiante de la Universidade de Santiago de Compostela celsofv9@yahoo.es

Adela Fuentes Canosa

Estudiante de la Universidade de Santiago de Compostela sanacuore@gmail.com

Patricia Rodríguez Groba

Estudiante de la Universidade de Santiago de Compostela patrigroba@hotmail.com

|Fecha presentación: 13/10/2011 | Aceptación: 03/11/2011 | Publicación: 23/12/2011

\section{Breve biografía del autor}

Steve Bowkett nació en los valles mineros del sur de Gales y empezó a escribir por placer a los trece años, poco después de trasladarse a la zona de Leicester, donde todavía reside. Orientó su carrera hacia la educación, de hecho, trabajó durante dieciocho años como docente de lengua inglesa, aunque en la actualidad dedica su tiempo principalmente a escribir, a formar a futuros docentes y a trabajar con niños de distintas edades para contribuir al desarrollo de sus capacidades creativas, emocionales y cognitivas.

Como autor, ha escrito novelas de fantasía y ciencia ficción para adolescentes y adultos, historias de horror, romance, ficción para preadolescentes e incluso libros de no ficción y poesía para lectores de todas las edades. También ha escrito una serie de libros sobre educación y desarrollo personal, entre los que destacan los siguientes títulos: Meditations for Busy People: how to stop worrying and stay calm, 10o+ Ideas for Teaching Thinking Skills, A Handbook of Creative Learning Activities and Jumpstart Creativity. Hasta la fecha, Steve Bowkett ha publicado más de cincuenta títulos y numerosos relatos cortos y poemas.

\section{Sobre la obra que nos ocupa}

Esta obra trata de romper con la tradición en lo que a la enseñanza de la competencia escrita se refiere y propone para ello una interesante alternativa. Steve Bowkett vuelve la vista atrás para recordarnos cómo la educación recibida en su infancia contribuyó a afianzar, si no desarrollar, el tan conocido miedo a la hoja en blanco. Ese y otros recuerdos son los que lo han animado a proponerse como objetivo armar a los docentes de las estrategias necesarias para conseguir que la enseñanza deje de anular nuestra creatividad innata y empiece a aprovecharla.

Así, define la creatividad en la escritura como la capacidad de establecer conexiones nuevas entre diferentes conceptos y adoptar una perspectiva múltiple al analizar una secuencia de ideas. Es decir, ser capaz de ver con diferentes ojos un mismo escenario. Sólo así conseguiremos producir pensamientos originales que nos permitan disfrutar de ese momento iEureka! que se produce cuando por fin nuestras ideas toman forma.

Claro que, como bien señala el autor, de nada serviría ser creativo si la riqueza del contenido de la historia no se acompaña de un correcto uso de las convenciones del género, de la forma y del estilo, algo para lo que también nos ofrece recursos a lo largo del libro.

Se trata de acabar con la idea de que para escribir historias lo que hace falta es pensar mucho. Al contrario, lo que se necesita es desarrollar una serie de competencias que solo se pueden alcanzar cuando los aprendices se sienten inmersos en una actividad para ellos motivadora y atractiva, que permita que poco a poco el alfabetismo surja de un modo tan lúdico como natural. Un alfabetismo que el autor no entiende ya como la simple habilidad para leer y escribir, sino como la capacidad de apropiarse del lenguaje, jugar con él, ponerlo a prueba, desafiarlo y, finalmente, emplearlo para dar vida a algo nuevo e individual. 


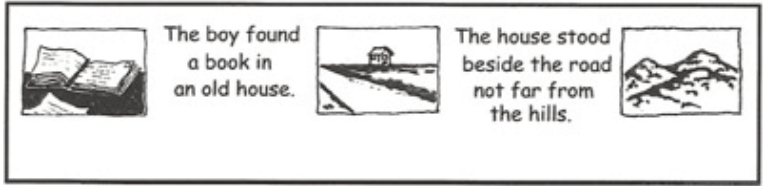

Figura 1. Tiras de imágenes para inspirar historias

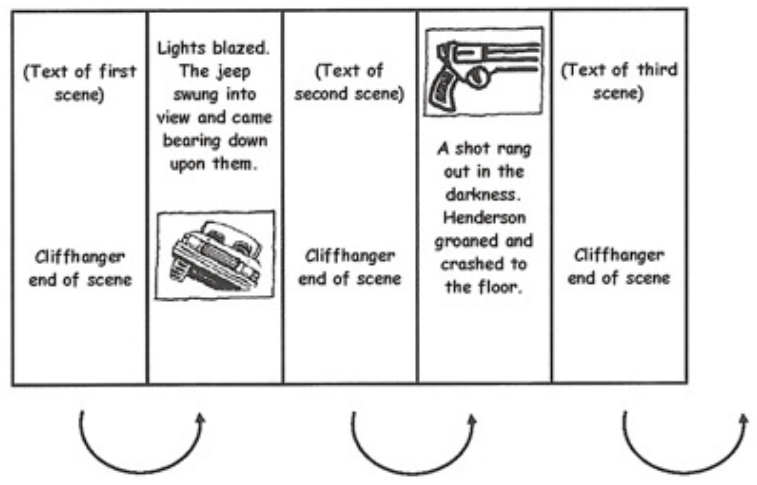

Figura 2. Líneas narrativas

Las técnicas y actividades propuestas en esta obra, de eminente carácter práctico, pueden adaptarse a las distintas capacidades y edades de los alumnos que, al fin y al cabo, son los auténticos destinatarios de las actividades. Constituyen propuestas que el autor organiza según el grado de complejidad y que, dentro de una estructura, permiten al maestro y al alumno una cierta flexibilidad. Además, dado que una imagen vale más que mil palabras, o como reformula el propio Bowkett, "puede evocar más de mil palabras", los recursos gráficos juegan aquí un papel fundamental.

En definitiva, con este libro el señor Bowkett se propone explicar cómo se pueden emplear fotografías e imágenes simples para ayudar a los niños a generar y organizar ideas de forma sistemática. A continuación veremos si su obra logra cumplir con ese ambicioso propósito.

\section{Análisis de la obra}

Los capítulos que componen esta obra se caracterizan por su brevedad y claridad. Se dividen en distintos apartados en los que se explica de forma visual y concisa cómo se organiza la actividad, cuáles son sus posibles beneficios de cara al aprendizaje, e incluso qué podríamos modificar para adaptar y complementar el ejercicio en función de los destinatarios. Además, como recurso adicional, la editora pone a disposición de los interesados, a través del sitio de Open-up Study Skills, una serie de materiales con actividades, capítulos de muestra y parrillas de ilustraciones gratuitas.

El libro consta de alrededor de cien páginas repartidas en cuatro secciones que a continuación describimos.

1. Getting Started: Compuesto por diez capítulos o actividades para iniciarnos en el uso de imágenes como inspiradoras de historias. Por ejemplo, el uso de tiras de imágenes que ayuden a construir frases y escenas cada vez más complejas, como podemos apreciar en la Figura 1:

2. Building Narrative: Partiendo de la conciencia de que no existen fórmulas exactas en la narrativa, el autor, a lo largo de estos ocho capítulos, se propone ayudar a los aprendices a ser capaces de razonar, discernir entre los diferentes caminos que puede seguir una historia y optar por aquel que

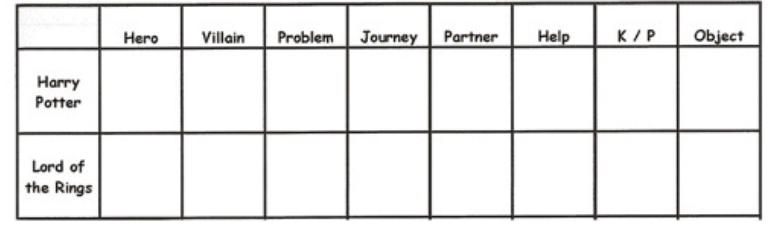

Figura 3. Tabla de características

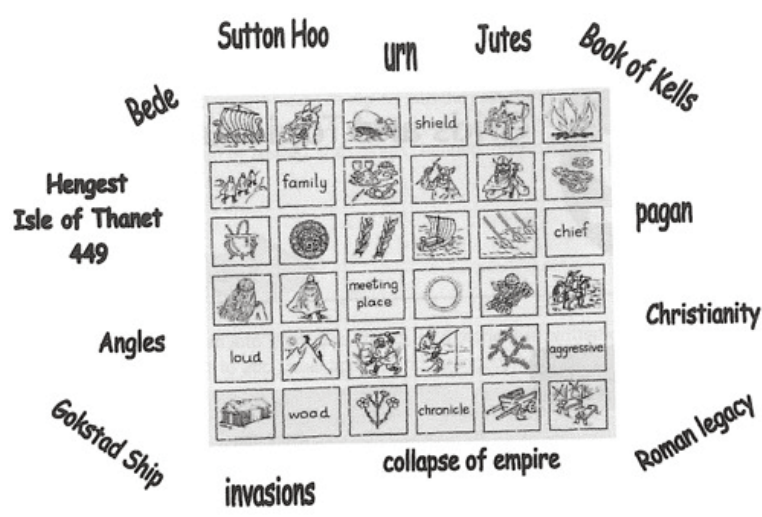

Figura 4. Cuadrícula de imágenes

le parezca más atractivo. $\mathrm{Al}$ mismo tiempo, los acerca a algunas herramientas útiles para la narración: partes de una historia, tipos de líneas narrativas, elementos narrativos básicos, uso de conectores, proverbios, suspense, etc. (ver Figura 2).

3. Enriching the Story: A lo largo de estos nueve capítulos se pretende proporcionar diferentes recursos que permitan a los estudiantes enriquecer sus historias y superar algunos de los tradicionales problemas que caracterizan sus creaciones, como la descripción del escenario y la repercusión que en la historia tienen la personalidad y las características particulares de los personajes (ver Figura 3)..

4. Story Grids: Esta última sección cuenta con seis capítulos y un apéndice en los que el autor presenta su principal herramienta, unas cuadrículas de imágenes escogidas temáticamente y dispuestas en parrillas de seis filas y seis columnas, así como varias formas de integrar este valioso material en la clase de lengua. Los niños, por ejemplo, usan un dado para ver lo que el azar puede aportar a sus historias: la imagen obtenida en una de las tiradas puede darles el protagonista, la siguiente indicar un problema y la tercera un posible desenlace. Incluso se abre la posibilidad de que los alumnos creen sus propias cuadrículas (ver Figura 4).

Finalmente, nos gustaría destacar que incluso en el aspecto formal se deja sentir el carácter didáctico del libro: un apartado para cada aspecto, múltiples y breves capítulos, imágenes ilustrativas... todo ello contribuye a que la lectura resulte práctica, amena y efectiva, ya que invita a poner en práctica lo sugerido.

\section{Conclusión}

Esta obra de Steve Bowkett nos ha conquistado, por lo que no tenemos reparo en considerarla altamente recomendable. ¿Por qué? A continuación ofrecemos algunos argumentos de peso.

En primer lugar, porque en ella se reflejan a la perfección los postulados del enfoque comunicativo y constructivista que actualmente, al menos en teoría, pretendemos instalar en nuestra aulas. Bowkett apuesta por el papel activo del 
alumno, constructor de su propio conocimiento, y por el desarrollo de una creatividad cuya importancia ha sido a menudo infravalorada y olvidada por el sistema educativo.

En segundo lugar, por su contenido, por ponernos en contacto con una nueva y sencilla forma de aprender y enseñar a escribir historias. Los ejercicios son tan motivadores, dinámicos y simples que el lector llega a plantearse: “¿por qué no se me habrá ocurrido a mí esto?”

En tercer lugar, por su redacción y organización, por la claridad con la que se expresa el autor y por su eminente carácter práctico. A menudo, los investigadores del mundo educativo centran su actividad en la crítica de lo vigente y en la teorización de posibles alternativas, sin que esas teorías se materialicen en auténticas propuestas concretas para las aulas. Steve Bowkett, sin embargo, ha sabido hacer frente a este problema ofreciendo una propuesta que parte de la teoría, sí, pero que en último término adopta una forma realmente práctica.

En cuarto lugar, recomendamos la lectura de este libro por tratarse de una iniciativa muy actual, innovadora y que el propio autor ha probado con éxito. Como buen profesor, ha aprendido antes de enseñar, ha analizado sus errores y sólo ahora, una vez perfeccionada su obra, pone a nuestra disposición un trabajo bien pulido.

En definitiva, una obra cuyo carácter didáctico y elevada carga de recursos visuales contribuirá a desarrollar la creatividad y mejorar la historias de todas aquellas clases en las que se haga un hueco. En la nuestra, sin duda, lo tendrá algún día. 